\title{
The Phytochemistry of Cell Recognition and Cell Surface Interactions
}

\section{Edited by}

Frank A. Loewus and

Clarence A. Ryan

Washington State University

Pullman, Washington

This volume examines the role of glycoproteins and other glycoconjugates as encountered in plants and other biological systems that interact with plants. Three general areas of this field of study are considered - an overview of the structures and properties of glycoconjugates, a detailed look at specific systems in terms of biological function, and selected examples of cell recognition and cell surface interactions as encountered in biology. Of special interest are chapters covering the structure and biosynthesis of certain glycoconjugates and the biochemical basis of adherence between bacteria and eukaryotic cells; the roles of several biologically active complex carbohydrates in plant-related host-pest relationships; extraction and properties of characteristic glycoproteins from plant tissues; the process of bacterial attachment to plant cell walls; and molecular events associated with pollen-stigma interactions and their immunochemistry.

A timely addition to the literature, The Phytochemistry of Cell Recognition and Cell Surface Interactions will be an important acquisition for researchers and workers in phytochemistry, biochemistry, botany, cell biology, and plant physiology.

Cover photograph: Sprays of sweet cherry

(Prunus avium L.) shortly after anthesis.

Photograph by Arden Literal, WSU, 1981 
recent advances in phytochemistry

volume 15

\section{The Phytochemistry of Cell Recognition and Cell Surface Interactions}




\section{RECENT ADVANCES IN PHYTOCHEMISTRY}

Proceedings of the Phytochemical Society of North America

\section{Recent Volumes in the Series}

Volume 9 Phytochemistry in Disease and Medicine

Proceedings of the Fourteenth Annual Meeting of the Phytochemical Society of North America, Western Carolina University, Cullowhee, North Carolina, August, 1974

Volume 10 Biochemical Interaction Between Plants and Insects

Proceedings of the Fifteenth Annual Meeting of the Phytochemical Society of North America, Tampa, Florida, August, 1975

Volume 11 The Structure, Biosynthesis, and Degradation of Wood Proceedings of the Sixteenth Annual Meeting of the Phytochemical Society of North America, Vancouver, Canada, August, 1976

\section{Volume 12 Biochemistry of Plant Phenolics}

Proceedings of the Joint Symposium of the Phytochemical Society of Europe and the Phytochemical Society of North America, Ghent, Belgium, August, 1977

Volume 13 Topics in the Biochemistry of Natural Products

Proceedings of the First Joint Meeting of the American Society of Pharmacognosy and the Phytochemical Society of North America, Stillwater, Oklahoma, August, 1978

\section{Volume 14 The Resource Potential in Phytochemistry}

Proceedings of the Nineteenth Annual Meeting of the Phytochemical Society of North America, Dekalb, Illinois, August, 1979

\section{Volume 15 The Phytochemistry of Cell Recognition and Cell Surface Interactions Proceedings of the First Joint Meeting of the Phytochemical Society of North America and the American Society of Plant Physiologists, Pullman, Washington, August, 1980}

A Continuation Order Plan is available for this series. A continuation order will bring delivery of each new volume immediately upon publication. Volumes are billed only upon actual shipment. For further information please contact the publisher. 
recent advances in phytochemistry

\section{volume 15}

\section{The Phytochemistry of Cell Recognition and Cell Surface Interactions}

Edited by

Frank A. Loewus

and

Clarence A. Ryan

Institute of Biological Chemistry

Washington State University

Pullman, Washington 
Library of Congress Cataloging in Publication Data

Main entry under title:

The Phytochemistry of cell recognition and cell surface interactions.

(Recent advances in phytochemistry; v. 15)

"Proceedings of the first joint meeting of the Phytochemical Society of North America and the American Society of Plant Physiologists, held August 4-7, 1980, at Washington State University, Pullman, Washington" - T.p. verso.

Includes bibliographies and index.

1. Plant cytochemistry-Congresses. 2. Cellular recognition-Congresses. 3. Cell interaction-Congresses. 4. Plant cell walls-Congresses. I. Loewus, Frank-Abel 1919- II. Ryan, Clarence A. III. Phytochemical Society of North America. IV. American Society of Plant Physiologists. V. Series.

QK861.R38 vol. 15 [QK725]

$581.19^{\prime} 2 \mathrm{~s}$

$81-10558$

ISBN-13: 978-1-4684-3988-5

e-ISBN-13: 978-1-4684-3986-1

DOI: $10.1007 / 978-1-4684-3986-1$

Proceedings of the First Joint Meeting of the Phytochemical Society of North America and the American Society of Plant Physiologists held August 4-7, 1980, at Washington State University, Pullman, Washington.

(c) 1981 Plenum Press, New York

Softcover reprint of the hardcover 1st edition 1981

A Division of Plenum Publishing Corporation

233 Spring Street, New York, N.Y. 10013

All rights reserved

No part of this book may be reproduced, stored in a retrieval system, or transmitted, in any form or by any means, electronic, mechanical, photocopying, microfilming, recording, or otherwise, without written permission from the Publisher 


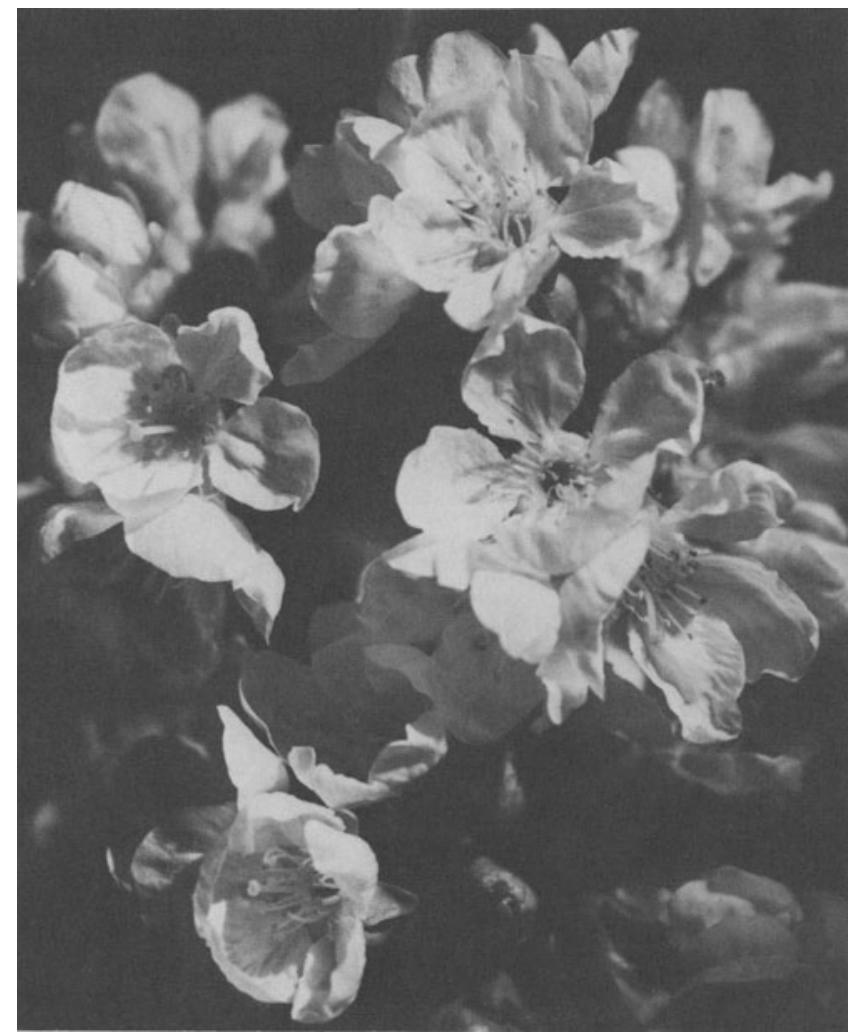

Sweet cherry (Prunus avium L.) Blossoms

Here, the process of recognition and interaction between pollen and pistil is expressed as growth of pollen tubes. Self-pollinations are incompatible, as are cross pollinations between varieties within the same S-genotype. In both incompatible and compatible pollinations, the initial events are presumably identical but only pollen tubes from compatible crosses continue to grow through the style until the ovary is reached. Imcompatible crosses result in arrested growth of pollen tubes within the style. See Chapter 8 by Clarke and Gleeson.

Photograph by Arden Literal, WSU, 1981 
The biological significance of carbohydrates in glycosylated biopolymers emerged from studies on viruses, microbial cells and animal tissues. Plant-related processes, a relative newcomer to this area of research, now offer challenging questions as regards the roles of glycosyl-conjugates and carbohydrate-binding proteins in such broadly based topics as pollination, fertilization, symbiosis (including nitrogen fixation), the chemical basis of morphogenesis, and the broad area of plant protection. While the impressive accomplishments on model systems, membrane-bound processes, receptor site biochemistry, and cell surface interactions fill numerous reports, reviews, and books, most of these involve biological systems other than plants. A real need exists for the present volume in which cell recognition and cell surface interactions as related to plants are examined.

Contributions to this volume may be sorted into three catagories: first an overview of the structures and properties of glycoconjugates, then a closer look at specific systems in terms of biological function, and finally, selected examples of cell recognition and cell surface interactions as encountered in biology. To introduce the general subject, Alan Elbein reviews the structure and biosynthesis of certain glycoconjugates and examines the biochemical basis of adherence between bacteria and eucaryotic cells. Irwin Goldstein examines the properties of plantderived lectins, in particular a group of lectins from Bandeiraea simplicifolia. The roles of several biologically-active complex carbohydrates in plant-related hostpest relationships are examined by Peter Albersheim and his colleagues. An in depth analysis of structural features found in exocellular and membrane-bound glycoconjugates of Penicillium charlesii is provided by John Gander and Cynthia Laybourne. Glycosidase activity accompanying phytohemaaglutinin properties of plant-derived carbohydrate-binding proteins is described by Leland Shannon and Charles Hankins. Robert Brown and $W$. C. Kimmins review their work on extraction and properties of two characteristic glycoproteins from Phaseolus vulgaris, the so-called hydroxyproline-rich and hydroxyproline-poor glycoproteins. 
Examples of cell recognition and cell surface interactions are drawn from five biological systems. Philip Larkin discusses plant protoplast agglutination and immobilization. Mariamne Whatley and Luis Sequeira review the process of bacterial attachment to plant cell walls, specifically the Agrobacterium tumefaciens, Pseudomonas spp., Xanthomonas and Erwinia, and Rhizobia nteractions. Molecular events associated with pollen-stigma interactions, including the immunochemistry of these events, are presented by Adrienne Clarke and Paul Gleeson. Daniel Janzen explores the role of lectins in plant-herbivore interactions. In the final chapter, Daniel McMahon looks at lectins as determinants for cell surface glycoconjugates of slime mold.

The occasion of this Symposium was the first joint meeting of the Phytochemical Society of North America and the American Society of Plant Physiologists (in conjunction with the Western Section of the latter Society). It was held August 4-7, 1980 at Washington State University, Pullman, Washington. Symposium organizers included Tsune Kosuge (Univ. Calif., Davis) and Rodeny Croteau (Washington State Univ., Pullman), as well as the editors of this volume. The moderators of the Symposium were Tsune Kosuge and Leonard Beevers (Univ. Okla., Norman).

The meeting came only 10 weeks after a cataclysmic eruption of Mount St. Helens in western Washington. Volcanic ash was spread over a third of the state including Pullman. Subsequent eruptions, though less devestating, threatened the very existance of the meeting but plant scientists, hardy souls that they are, challenged Vulcan at his very doorstep. Over 1,200 attended the meeting and were rewarded with fair skies, balmy weather and a chance to listen to the eleven outstanding papers found in this volume.

The organizers and editors wish to thank all contributors for their efforts and prompt submission of manuscripts. Particular thanks goes to the National Science Foundation for a grant in support of travel for our participants and to the Graduate School, Washington State University and the Western Section, ASPP for generous funds. It was these sources that brought us to our goal.

Finally, acknowledgement must be made to Jane Bower in the Word Processing Center, College of Agriculture, Washington State University, under the direction of Doris Birch who provided camera-ready copy of excellent quality. 


\section{CONTENTS}

1. The Structure and Biosynthesis of Lipopolysaccharides and Glycoproteins . . . . . . . . . . 1
A. D. Elbein

2. Plant Derived Lectins . . . . . . . . . .

I. J. Goldstein

3. Structure and Function of Complex Carbohydrates Active in Regulating the Interactions of Plants and Their Pests . . . . . . . . . . . . . .

P. Albersheim, M. McNeil, A. G. Darvill,

B. S. Valent, M. G. Hahn, B. K. Robertsen, and

P. Aman

4. Galactofuranosy1-Containing Lipoglycopeptide in Penicillium .. . . . . . . . . . . . . 59

J. E. Gander and C. J. Laybourn

5. Enzymatic Properties of Phytohemagglutinins . . . 93

L. M. Shannon and C. N. Hankins

6. Recovery of Glycoproteins from Plant Tissues . . . 115

R. G. Brown and W. C. Kimmins

7. Plant Protoplast Agglutination and Immobilization.

P. J. Larkin

8. Molecular Aspects of Recognition and Response in the Pollen-Stigma Interaction. . . . . . . . . . 161 A. E. Clarke and P. A. Gleeson 
9. Bacterial Attachment to Plant Cell Walls . . . . 213

M. H. Whatley and L. Sequeira

10. Lectins and Plant-Herbivore Interactions . . . . 241

D. H. Janzen

11. Cell Interactions and Pattern Formation in

Dictyostelium discoideum . . . . . . . . 259

D. McMahon

Index . . . . . . . . . . . . . . . . . . 273 